\title{
Electrochemical Behavior of Rhodium Acetamidate Immobilized on a Carbon Paste Electrode: a Hydrazine Sensor
}

\author{
Eric de S. Gil and Lauro T. Kubota*
}

\author{
Instituto de Química, Universidade Estadual de Campinas, CP 6154, 13083-970, Campinas - SP, Brazil.
}

\begin{abstract}
O comportamento eletroquímico do acetamidato de ródio imobilizado em pasta de carbono e as potencialidades para construção de sensores foram avaliados. O complexo imobilizado mostrou boa estabilidade e propriedades redox, sendo observados dois pares redox reversíveis com potenciais médios entre 0,15 e $0,55 \mathrm{~V}$ vs SCE. Entretanto, a resolução dos picos voltamétricos mostrou-se dependente do eletrólito suporte. A correlação entre a capacidade coordenante do eletrólito e seus respectivos potenciais médios sugere que o eletrólito deve coordenar-se em posição axial nos complexos. Além disto, a posição axial deve ser o sítio catalítico, sendo que a oxidação de espécies doadoras, como hidrazina, foi catalisada por estes complexos. O baixo potencial $(<300 \mathrm{mV})$ mostra uma boa viabilidade deste composto para a confecção de sensores para a hidrazina, minimizando problemas de interferentes. Uma boa faixa de resposta linear para a hidrazina foi ajustada pela equação $\mathrm{i}=23,13( \pm 0,34) \mathrm{c}$, onde $\mathrm{i}=$ corrente $\mathrm{em} \mathrm{mA}$ and $\mathrm{c}=$ concentração em mol dm ${ }^{-3}$ na faixa de 10-5 a 10-2 mol dm-3. O baixo tempo de resposta ( 1 s) poderia ser útil em análises por injeção em fluxo. Este sistema foi bem estável e apresentou boa repetibilidade, mesmo após 30 medições, com uma variância de $0,5 \%$.
\end{abstract}

The electrochemical behavior of rhodium acetamidate immobilized in carbon paste electrode and the consequences for sensor construction were evaluated. The electrode showed good stability and redox properties. Two reversible redox couples with midpoint potentials between 0.15 and 0.55 $\mathrm{V} v s \mathrm{SCE}$ were observed. However, peak resolution in voltammetric studies was very dependent on the supporting electrolyte. The correlation between coordinating power of the electrolyte and peak potential suggests that the electrolyte can coordinate through the axial position of the complexes. Furthermore, the axial position may be also the catalytic site, as a catalytical response was observed for hydrazine oxidation. A good linear response range for hydrazine was fit by the equation $i=23.13$ $( \pm 0.34) \mathrm{c}$, where $\mathrm{i}=$ current in $\mathrm{mA}$ and $\mathrm{c}=$ concentration in $\mathrm{mol} \mathrm{dm}^{-3}$ in the range of $10^{-5}$ up to $10^{-2} \mathrm{~mol} \mathrm{dm}^{-3}$. The low applied potential $(<300 \mathrm{mV})$ indicates a good device for hydrazine sensor, minimizing interference problems. The short response time $(\sim 1 \mathrm{~s})$ may be useful in flow injection analysis. Furthermore, this system was very stable presenting good repeatability even after 30 measurements with a variance of $0.5 \%$.

Keywords: rhodium acetamidate, electrochemical sensors, hydrazine determination, carbon paste electrode, polyethylenimine

\section{Introduction}

The researches for the development of new sensors have been a subject of great interest ${ }^{1-3}$. The greatest challenge in this field is the combination of the selectivity, sensitivity, simplicity, rapidity ${ }^{4-5}$.

These characteristics are very important in analytical chemistry, mainly in complex samples ${ }^{6}$. In order to improve these characteristics the use of new materials in sensors has included many species such as metal complexes ${ }^{7}$, enzymes ${ }^{8}$

\footnotetext{
*e-mail: kubota@iqm.unicamp.br
}

and $\mathrm{DNA}^{9}$. These modifications consist in immobilizing some catalyst or electron mediator species to electrocatalyze the oxidation or reduction of target analytes without application of high overpotentials ${ }^{7-9}$. For this purpose, the use of Rhodium Acetamidate Modified Electrode (RAME) has been described ${ }^{10}$. This complex presents few electrochemical studies, all of which in non-aqueous solution. Thus, it is very important in the sensors construction, to study the electrochemical behaviour, specially that of the immobilized complex that is unleachable in aqueous solutions. Furthermore, this complex belongs to an excellent class of catalysts and potential antitumour agents ${ }^{11-13}$. Concerning 
the cytostatic activity of these species, the most commonly proposed interaction is the axial $(\mathrm{L})$ coordination (Figure 1) through nitrogen, oxygen or sulfur atoms of enzymes or DNA $^{11,12}$. Hence, the affinity of rhodium complexes for nitrogenated groups could be exploited to increase the selectivity for nitrogen-bearing analytes, while their catalytic power can improve the sensitivity ${ }^{12}$. On the other hand, the biological significance of hydrazine compounds requires versatile methods for environmental and industrial monitoring for its determination at low levels ${ }^{14,15}$. Besides, this molecule presents great reactivity and high affinity by metal centers, where it can be oxidized ${ }^{16}$. Based on this context, the electrochemistry of rhodium acetamidate immobilized on carbon paste was studied and its possible aplication for hydrazine sensing investigated.

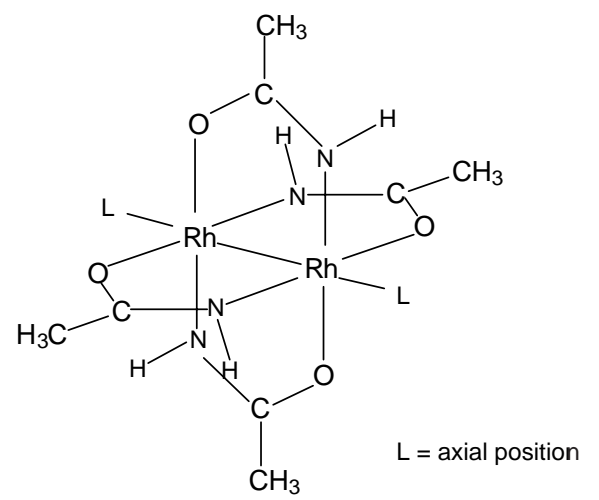

Figure 1. Structure of rhodium acetamidate.

\section{Experimental}

\section{Chemicals}

Rhodium acetamidate was synthesized by stepwise exchange reaction of $\left[\mathrm{Rh}_{2}\left(\mathrm{O}_{2} \mathrm{CCH}_{3}\right)_{4}\right]$ with acetamide as previously described ${ }^{17}$. The carbon powder was purchased from BDH (Poole UK). Polyethylenimine and hydrazine were from Sigma Chemical Co. All salts used for the electrochemical studies were of analytical grade.

\section{Electrochemicalbehavior of rhodiumacetamidate solubilized in aqueous solutions}

The midpoint potential for $1.0 \times 10^{-3} \mathrm{~mol} \mathrm{dm}^{-3}$ $\left[\mathrm{Rh}_{2}\left(\mathrm{HNOCCH}_{3}\right)_{4}\right]$ aqueous solution with $0.5 \mathrm{~mol} \mathrm{dm}^{-3}$ $\mathrm{KCl}, \mathrm{pH} 7$, was determined by scanning the potential in a range of 0-800 $\mathrm{mV}$ with scan rate of $25 \mathrm{mV} \mathrm{s}^{-1}$.

\section{Preparation of RAME}

The carbon paste modified electrode was prepared in three steps: 1) mixing $80 \mathrm{mg}$ of graphite powder (99.9\%) with $6 \mathrm{mg}$ of rhodium acetamidate and $100 \mathrm{~mm}^{-3}$ of PEI $1 \%$ (water solution), 2) drying of this mixture at room temperature and 3) adding enough mineral oil to form a paste. This paste was put into a cavity of the platinum disk of 1 $\mathrm{mm}$ deep and $5 \mathrm{~mm}$ diameter sealed in the extremity of a glass tube.

\section{Studies of supporting electrolyte effects}

The effects of the nature of supporting electrolyte investigation was carried out by using $0.5 \mathrm{~mol} \mathrm{dm}^{-3} \mathrm{KCl}$, $\mathrm{NaCl}, \mathrm{LiCl}, \mathrm{KAc}, \mathrm{KNO}_{3}$ and $\mathrm{K}_{2} \mathrm{SO}_{4}$ solutions at $\mathrm{pH}$. The cyclic voltammograms were recorded in the potential range of $0-800 \mathrm{mV}$ at a scan rate of $10 \mathrm{mV} \mathrm{s}^{-1}$. The studies of the electrolyte concentration influence were carried out for $\mathrm{KCl}$ and $\mathrm{KNO}_{3}$ in the concentration range of 0.1 up to 1.0 $\mathrm{mol} \mathrm{dm}{ }^{-3}$.

\section{pHinfluence}

The studies of solution $\mathrm{pH}$ were evaluated over the range from 0 up to $800 \mathrm{mV} v s \mathrm{SCE}$, in $0.5 \mathrm{~mol} \mathrm{dm}^{-3} \mathrm{KNO}_{3}$ and $\mathrm{KCl}$. The solution $\mathrm{pH}$ between 2 and 8 was adjusted with dilute $\mathrm{HCl}$ or $\mathrm{NaOH}$ solutions. The scan rate for these studies was $10 \mathrm{mV} \mathrm{s}^{-1}$, keeping the ionic strength in 0.5 $\mathrm{mol} \mathrm{dm}{ }^{-3}$.

\section{Studies of the scan rate and stability}

These studies were carried out in $0.5 \mathrm{~mol} \mathrm{dm}^{-3} \mathrm{KCl}$ and $\mathrm{KNO}_{3}$ at $\mathrm{pH} 7$, with scan rates of 2, 5, 10, 20, 30, 40, 50 and $60 \mathrm{mV} \mathrm{s}^{-1}(0-800 \mathrm{mV})$. In order to verify the stability of this system, 40 cycles were carried out at a scan rate of $10 \mathrm{mVs}^{-1}$ and 10 cycles at $2 \mathrm{mVs}^{-1}$, immediately after the preparation of the paste and after 4 months of storage.

\section{Catalyticactivitiy}

The catalytic activity was initially evaluated by means of cyclic voltammetry in the same potential range used for all other studies $(0-800 \mathrm{mV})$, by dropwise addition of 50 $\mathrm{mm}^{3}$ of $0.2 \mathrm{~mol} \mathrm{dm}^{-3}$ hydrazine solution, in an electrochemical cell containing $5 \mathrm{~cm}^{3}$ of $0.5 \mathrm{~mol} \mathrm{dm}^{-3} \mathrm{KCl}$ solution at $\mathrm{pH}$. The scan rate was $10 \mathrm{mV} \mathrm{s}^{-1}$.

\section{Chronoamperometric studies}

For the calibration curves, the electrochemical cell was filled with $5 \mathrm{~cm}^{3}$ of $0.5 \mathrm{~mol} \mathrm{dm} \mathrm{m}^{-3} \mathrm{KCl}$ solution at $\mathrm{pH} 7$, fixing the potential in $300 \mathrm{mV} v s$. SCE and the rotation speed of the electrode in $200 \mathrm{rpm}$. The addition of $50 \mathrm{~mm}^{3}$ of a $0.02 \mathrm{~mol} \mathrm{dm}^{-3}$ hydrazine solution was carried out step by step. 


\section{Instrumentation}

The electrochemical measurements were made on a Princeton Applied Research (PAR) 273A potentiostat/ galvanostat and a Pine AFMSRX 002 rotatory system. The solutions $\mathrm{pH}$ were adjusted with the aid of a Corning 450 $\mathrm{pH} /$ ion meter. The cyclic voltammetry measurements were carried out utilizing a three-electrode system. The working electrodes were a platinum-disk electrode (to study of free rhodium acetamidate in aqueous solution) and Rhodium Acetamidate Modified Electrode (RAME). The reference electrode was a saturated calomel electrode (SCE), and a platinum wire was used as the counter electrode.

\section{Results and Discussion}

\section{Cyclic voltammetry behavior of soluble $\left[\mathrm{Rh}_{2}\left(\mathrm{O}_{2} \mathrm{CCH}_{3}\right)_{4}\right]$ in aqueous solution.}

The electrochemical behavior of rhodium acetamidate and other dimeric analogues found in the literature until now have been investigated only in non aqueous systems. There is an agreement that the oxidation processes are metal centered and that they occur in two steps with distinct formal potentials $\left(\mathrm{E}_{\mathrm{m} 1} \text { and } \mathrm{E}_{\mathrm{m} 2}\right)^{12,17,18}$ :

$$
\begin{aligned}
& \mathrm{E}_{\mathrm{m} 1} \mathrm{Rh}^{\mathrm{II}} / \mathrm{Rh}^{\mathrm{II}} \text {,III: }\left[\mathrm{Rh}_{2}\left(\mathrm{HNOCCH}_{3}\right)_{4}(\mathrm{~S})_{2}\right] \leftrightarrow \\
& {\left[\mathrm{Rh}_{2}\left(\mathrm{HNOCCH}_{3}\right)_{4}(\mathrm{~S})_{2}\right]^{+}+1 \mathrm{e}^{-}}
\end{aligned}
$$

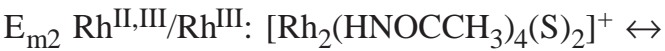

$$
\begin{aligned}
& {\left[\mathrm{Rh}_{2}\left(\mathrm{HNOCCH}_{3}\right)_{4}(\mathrm{~S})_{2}\right]^{2+}+1 \mathrm{e}^{-}}
\end{aligned}
$$

Comparison between $\left.\left[\mathrm{Rh}_{2} \text { (acetate) }\right)_{4}\right]$ and $\left[\mathrm{Rh}_{2}\right.$ (acetamidate $\left.{ }_{4}\right]$ shows that these processes are shifted to lower potentials when the bridging acetate groups from the equatorial positions are changed by acetamidates, due to the stronger basicity of the amide. This will stabilize the oxidized form, since the electron density on the two metal centers is increased. Indeed, for each equatorial group exchanged, a decrease of $225 \mathrm{mV}$ in its midpoint potential $\mathrm{E}_{\mathrm{m}}$ [where: $\mathrm{E}_{\mathrm{m}}=\left(\mathrm{E}_{\mathrm{a}}+\mathrm{E}_{\mathrm{c}}\right) / 2$ ] is observed ${ }^{18}$. Less intense effects are also observed upon changing ligangs in the axial positions ${ }^{17-19}$. Table 1 shows the values for both midpoint potentials $\left(\mathrm{E}_{\mathrm{m} 1}\right.$ and $\left.\mathrm{E}_{\mathrm{m} 2}\right)$ obtained for rhodium acetamidates under the same conditions in different solvents. A linear inverse correlation between electron donor power and $\mathrm{E}_{\mathrm{m}}$ was observed, except for dimethylsulfoxide (DMSO) and triphenylphosphine $\left(\mathrm{PPh}_{3}\right)$, in $\mathrm{CH}_{2} \mathrm{Cl}_{2}$. This fact was assigned to the $\pi$ back-donation mechanism from the $\mathrm{Rh}-\mathrm{Rh}$ to $\mathrm{DMSO}$ or $\mathrm{PPh}_{3}$ which withdraws some electron density from the metal centers ${ }^{19}$. The influence of axial ligands was also observed for aqueous systems in our experiments. The axial coordination with chloride anions (Table 2) resulted in a significant shift towards lower potentials, when compared to the literature data (Table 1). These observations agree with the literature data, that show that redox processes are favored by axial coordination which stabilizes the intermediate species or makes the oxidation process easier by increasing the electron density ${ }^{17-19}$. Furthermore, in the presence of higher $\mathrm{Cl}^{-}$levels a decrease in $\Delta \mathrm{E}$ or about $100 \mathrm{mV}$ for $\mathrm{E}_{\mathrm{m} 1}$ and $50 \mathrm{mV}$ for $\mathrm{E}_{\mathrm{m} 2}$ was observed (scan rate of $25 \mathrm{mV} \mathrm{s}^{-1}$ ). These facts show that the chloride ion enhances the electron transfer.

Table 1. $\mathrm{E}_{\mathrm{m} 1}$ and $\mathrm{E}_{\mathrm{m} 2}$ values $(\mathrm{mV})$ for rhodium acetamidate in different media.

\begin{tabular}{lccc}
\hline SOLVENT & $\mathrm{E}_{\mathrm{m} 1}$ & $\mathrm{E}_{\mathrm{m} 2}$ & Ref. \\
\hline Acetonitrile & 150 & 1.410 & {$[18]$} \\
Pyridine & 80 & - & {$[17]$} \\
Dimethylsulfoxide & 310 & - & {$[17]$} \\
$\mathrm{PPh}_{3} 0.1 \mathrm{~mol} \mathrm{dm}^{-3} / \mathrm{CH}_{2} \mathrm{Cl}_{2}$ & 250 & 1.650 & {$[17]$} \\
\hline
\end{tabular}

Table 2. $\mathrm{E}_{\mathrm{m} 1}$ and $\mathrm{E}_{\mathrm{m} 2}$ values $(\mathrm{mV})$ for rhodium acetamidate $1.0 \mathrm{x}$ $10^{-3} \mathrm{~mol} \mathrm{dm}^{-3}$ in different supporting electrolytes, obtained with a platinum disk electrode.

\begin{tabular}{lcc}
\hline SOLVENT & $\mathrm{E}_{\mathrm{m} 1}$ & $\mathrm{E}_{\mathrm{m} 2}$ \\
\hline aqueous $0.1 \mathrm{~mol} \mathrm{dm}^{-3} \mathrm{KNO}_{3}$ & 280 & 492 \\
aqueous $0.1 \mathrm{~mol} \mathrm{dm}^{-3} \mathrm{KCl}$ & 270 & 470 \\
aqueous $0.5 \mathrm{~mol} \mathrm{dm}^{-3} \mathrm{KCl}$ & 250 & 381 \\
\hline
\end{tabular}

\section{Electrochemicalbehavior of RAME in different electrolytes}

The electrochemical experiments were undertaken in aqueous solutions, since the aim of this work was the development of sensors, which could be useful for biological applications. The midpoint potentials were determined in aqueous electrolyte solutions (Figure 2) and they are listed in Table 3.

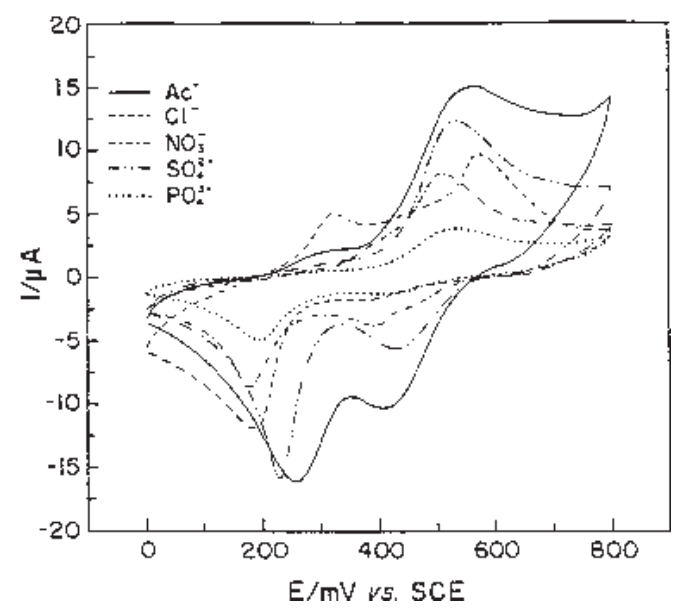

Figure 2. Cyclic voltammograms of RAME (2nd cycle) in different anions supporting electrolyte solutions $\left(0.5 \mathrm{~mol} \mathrm{dm}^{-3}, \mathrm{pH} 7,0-800\right.$ $\left.\mathrm{mV}, 10 \mathrm{mVs}^{-1}\right)$. 
Table 3. Midpoint potentials $\left(\mathrm{E}_{\mathrm{m} 1}\right.$ and $\left.\mathrm{E}_{\mathrm{m} 2}\right)$ obtained for RAME in different electrolytes.

\begin{tabular}{lcc}
\hline Electrolytes & $\mathrm{E}_{\mathrm{m} 1} / \mathrm{mV}$ & $\mathrm{E}_{\mathrm{m} 2} / \mathrm{mV}$ \\
\hline $\mathrm{LiCl}$ & 240 & - \\
$\mathrm{NaCl}$ & 240 & - \\
$\mathrm{KCl}$ & 240 & - \\
$\mathrm{KNO}_{3}$ & - & 422 \\
$\mathrm{~K}_{2} \mathrm{SO}_{4}$ & - & 469 \\
$\mathrm{KAc}^{-1}$ & - & 446 \\
\hline $\mathrm{mV} \mathrm{s}^{-1}$, [electrolyte] $=0.5 \mathrm{~mol} \mathrm{dm}^{-3}, \mathrm{pH} \mathrm{7.}$ &
\end{tabular}

The most interesting fact to be higlighted is that coordinating anions like chloride can induce the appearance of the first oxidation peak. It should be correlated with the formation of an intermediate species $\mathrm{Rh}_{2}$ II,III, which appears only after the second cycle when the complex is immobilized (Figure 3). For the other non-coordinating electrolytes, the first anodic peak is not well visualized while the resolution of the second reduction peak is slightly improved (Figure 2). This behavior can be explained by the interaction between immobilized complexes and electrolytes being more difficult than those observed for soluble ones. Hence, the first cycle is necessary to form $\left[\mathrm{Rh}_{2}{ }^{\mathrm{III}}\right]^{2+}$ species, which has higher affinity for anionic species. Furthermore, the interaction between complex and electrolytes may be more effective through the axial position ${ }^{17-19}$. For this reason, voltammograms in the presence of coordinating anions such as chloride may exhibit different patterns from those with noncoordinating anions. Thus, the chloride anions can form adducts with these dimers, due to its stronger interaction in the axial positions. The formation constants reported for the first coordination are much higher than for the second, and upon decreasing the concentrations of the ligand the coordination become more difficult ${ }^{12}$. Thus, different species can be formed depending on the chloride concentration in the medium. For soluble complexes larger shifts in the midpoint potentials were observed depending on the supporting electrolytes. In the particular case of aqueous solutions containing chloride, it was observed that these shifts were also dependent on their concentrations.

The remarkable effects of chloride anions were also observed for RAME, not only when their concentration was changed (Figure 3), but also when the counterion was exchanged for more electropositive and mobile cations (Figure 4).

In Figures 3 and 4, it can be noted that the same splitting pattern observed for lower chloride concentrations was also observed for lithium supporting electrolyte solution. In both cases, these splittings can be correlated to the formation constants, which can result in different coordination species. Thus, in case of chloride anions the formation constants may be dependent on the concentration levels and electropositivity (anion affinitiy) of the cations.

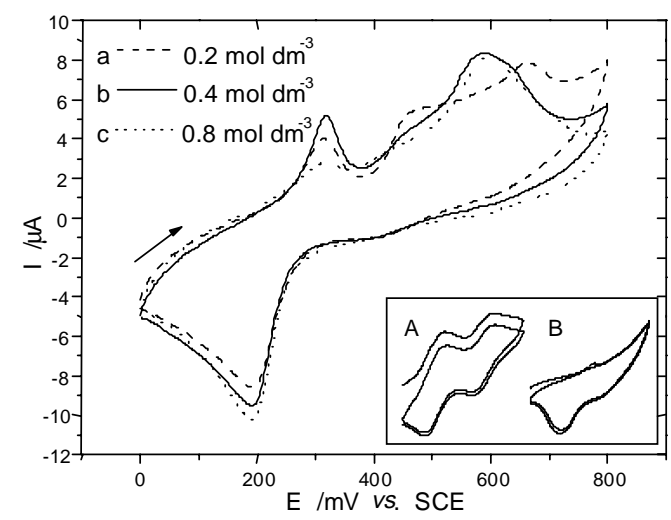

Figure 3. Cyclic voltammograms of RAME in different concentration of $\mathrm{KCl}$ solutions $\left(0.2,0.4,0.8 \mathrm{~mol} \mathrm{dm}^{-3}, \mathrm{pH} 7,0-800 \mathrm{mV}, 10\right.$ $\left.\mathrm{mVs}^{-1}\right)$, [in the box: $1^{\text {st }}$ and $2^{\text {nd }}$ cycle for A) soluble, B) immobilized complex $\left.\left(0.5 \mathrm{~mol} \mathrm{dm}^{-3} \mathrm{KCl}, \mathrm{pH} 7,25 \mathrm{mV} \mathrm{s}^{-1} 0-650 \mathrm{mV}\right)\right]$.

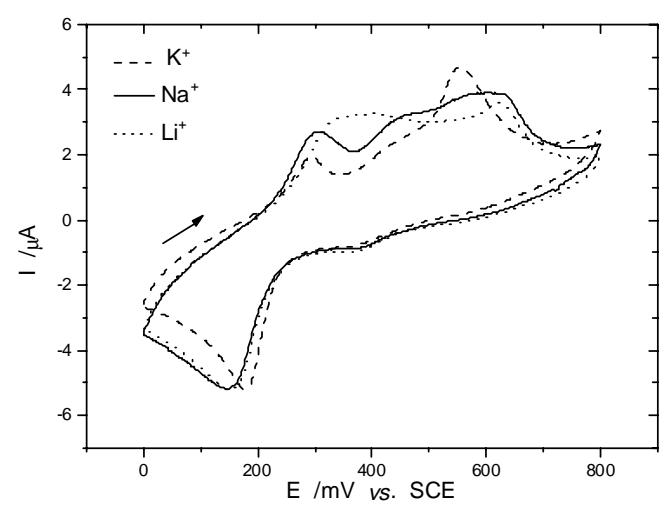

Figure 4. Cyclic voltammograms of RAME in $0.5 \mathrm{~mol} \mathrm{dm}^{-3} \mathrm{MCl}$ supporting electrolyte solutions $(\mathrm{M}=\mathrm{Li}, \mathrm{Na}, \mathrm{K})$ at $\mathrm{pH} 7$, potential range of $0-800 \mathrm{mV}$, and scan rate of $10 \mathrm{mV} \mathrm{s}^{-1}$ ).

In addition, RAME presented different ratios between cathodic and anodic peaks depending on the kind of the electrolyte (coordinating or non-coordinating) (Figure 2). Indeed, only one of the midpoint potentials could be determined precisely ( $\mathrm{E}_{\mathrm{m} 1}$ for chloride and $\mathrm{E}_{\mathrm{m} 2}$ for the non-coordinating anions). In order to evaluate both processes two kinds of electrolytes were used for solution $\mathrm{pH}$ effect evaluation on RAME behavior (Table 3). The formal potential invariance on the $\mathrm{pH}$ between 2 and 8 agrees with the literature data, where the redox process is metal centered ${ }^{17-19}$.

In Table 4, great differences on the current ratio between cathodic and anodic peaks can be verified. These differences were observed only for the immobilized complex, while for soluble ones these ratios remained very close to the unity, suggesting an easier interaction in the former case. The non-proportionality of these current ratios and the reversibility of RAME suggested that both processes could be interdependent. In order to confirm this hypothesis, voltammograms with different switching potentials (Figure 5) were detained out. Figure 5a clearly 
shows that the first cathodic peak is completely suppressed, when the switching potentials are lower than those required to get the second anodic peak for RAME. It is important to note that for the soluble complex no interdependence between $\mathrm{E}_{\mathrm{m} 1}$ and $\mathrm{E}_{\mathrm{m} 2}$ was observed (Figure $5 \mathrm{~b}$ ). Thus, the rever-sibility of each redox couple was somewhat impaired after the immobilization.

Table 4. Current ratio and midpoint potentials $(\mathrm{mV})$ in different $\mathrm{pH}$, obtained for RAME vs SCE in solutions of $0.5 \mathrm{~mol} \mathrm{dm}^{-3}$ of $\mathrm{KCl}$ or $\mathrm{KNO}_{3}$

\begin{tabular}{ccccc}
\hline $\mathrm{pH}$ & $\mathrm{E}_{\mathrm{m} 1}(\mathrm{KCl})$ & $\mathrm{I}_{1 \mathrm{~A}} / \mathrm{I}_{1 \mathrm{C}}$ & $\mathrm{E}_{\mathrm{m} 2}\left(\mathrm{KNO}_{3}\right)$ & $\mathrm{I}_{2 \mathrm{~A}} / \mathrm{I}_{2 \mathrm{C}}$ \\
\hline 2 & 258 & 0.33 & 426 & 1.73 \\
3 & 259 & 0.34 & 424 & 1.73 \\
4 & 260 & 0.35 & 420 & 1.72 \\
5 & 261 & 0.36 & 421 & 1.72 \\
6 & 262 & 0.37 & 420 & 1.71 \\
7 & 261 & 0.38 & 420 & 1.72 \\
8 & 262 & 0.39 & 424 & 1.73 \\
\hline
\end{tabular}
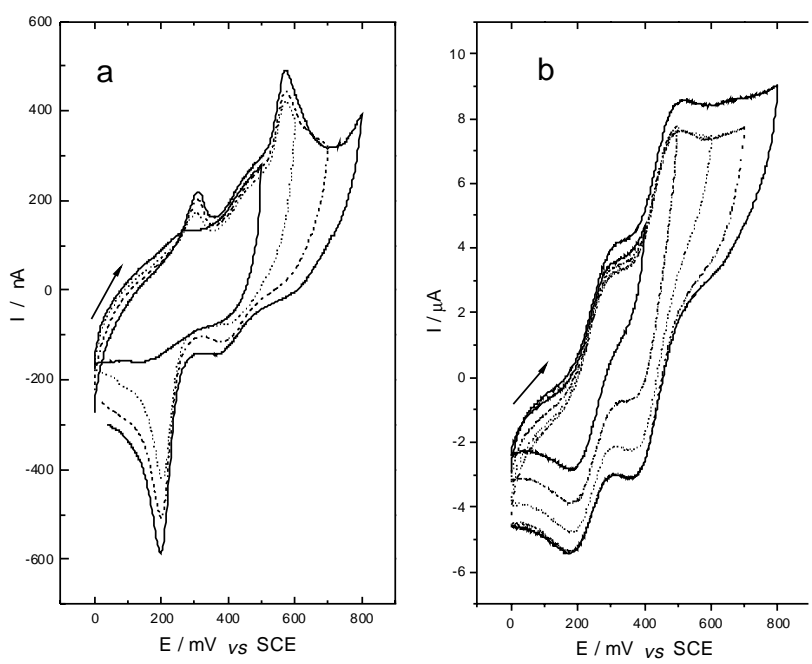

Figure 5. Cyclic voltammograms with different switching potentials for a)"immobilized complex" (RAME), and b) "soluble complex" at concentration of $1.0 \times 10^{-3} \mathrm{~mol} \mathrm{dm}^{-3}$ both in the following conditions: $0.5 \mathrm{~mol} \mathrm{dm}^{-3} \mathrm{KCl}, \mathrm{pH} 7,0-800 \mathrm{mV}, 10 \mathrm{mV} \mathrm{s}^{-1}$.

\section{Studies of scan rate}

The increase of the scan rate provoked an increase in the $\Delta \mathrm{E}$ value. The resulting plot $\mathrm{i}_{\mathrm{pa}} v s \mathrm{v}^{1 / 2}$ (Figure 6) is linear in the range between 2 and $60 \mathrm{mV} \mathrm{s}^{-1}$. This behavior indicates that diffusion-controlled redox process occurs in the system. However, this system presented very good stability even after 4 months of storage or in continuous use. This behavior suggests that the complex is strongly adsorbed and the supporting electrolytes should be responsible for the charge compensation, explaining the diffusion controlled process.

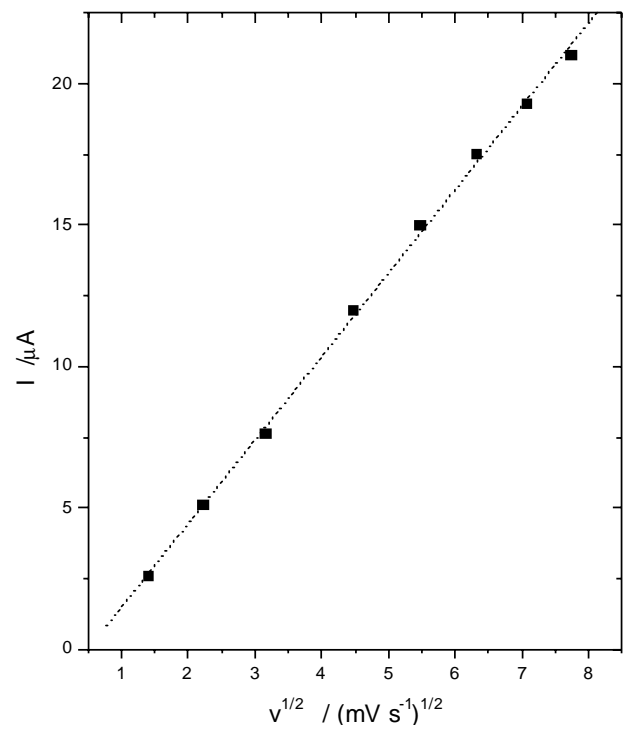

Figure 6. Dependence on the second anodic peak current at a function of $\mathrm{v}^{1 / 2}$ obtained for RAME $\left(\mathrm{KCl} 0.5 \mathrm{~mol} \mathrm{dm}^{-3}, \mathrm{pH} 7\right)$.

\section{Catalytic activity for hydrazine electrooxidation}

The electrocatalytic activity of the rhodium complex was verified initially by cyclic voltammetry. The catalytic power of this system showed to be very efficient for hydrazine oxidation, due to the bubbles formed (probably nitrogen) on the surface of RAME. To improve its performance a rotatory system was used, in which at least 100 rpm were needed to avoid the bubble deposition on the electrode surface. The catalytic efficiency was better in the $\mathrm{pH}$ between 5 and 9 (Figure 7). The anodic peak current decreases meaningfully below $\mathrm{pH} 5$, when no catalytic response was observed under strongly acidic conditions, due to the lower affinity between protonated hydrazine and metallic center.

Furthermore, under alkaline conditions $(\mathrm{pH}>8)$, the response begins to decrease slowly because the stability of rhodium acetamidate is not so good in alkaline conditions, thus the $\mathrm{pH} 7$ was chosen for the measurements. The catalytic reaction starts effectively at low potentials like 150 $\mathrm{mV}$, and the response increases sharply after $200 \mathrm{mV}$ up to $350 \mathrm{mV}$ when it reaches a maximun current level (Figure 8). These potentials were very low, since that hydrazine is oxidized on a platinum disk electrode at $1.16 \mathrm{~V} 20$.

The applied potential of $300 \mathrm{mV} v s$ SCE, pH 7 and 200 rpm were employed in all subsequent work, as a compromise between sensitivity and selectivity. Under these conditions, a good linear response range between $1.0 \times 10^{-5}$ and $1.0 \times 10^{-2} \mathrm{~mol} \mathrm{dm}^{-3}$ hydrazine concentration was observed, fit by the equation $\mathrm{i}=23.13( \pm 0.34) \mathrm{c}$ with a correlation coefficient of 0.9988 for $\mathrm{n}=15$, where the current $(i)$ is given in $\mathrm{mA}$ and hydrazine concentration (c) in $\mathrm{mol} \mathrm{dm}^{-3}$. 


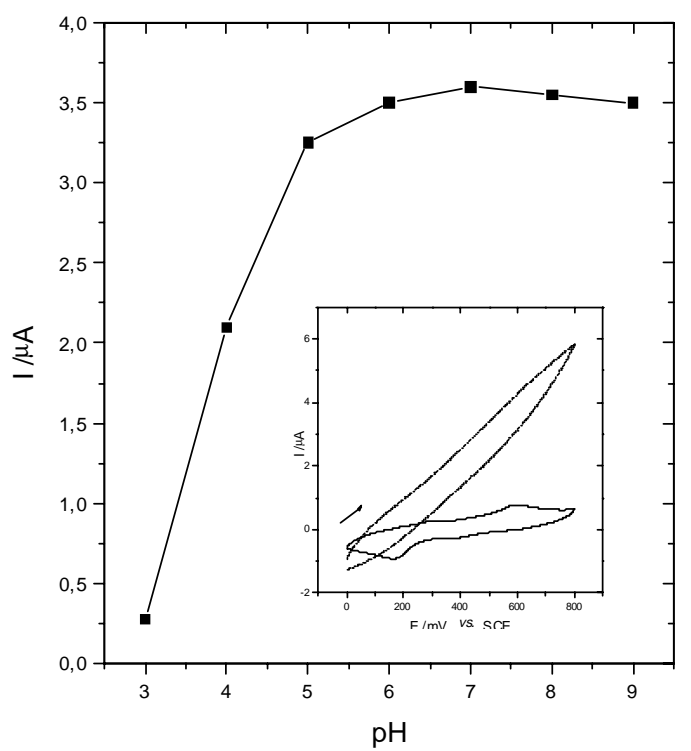

Figure 7. Plot of the oxidation peak currents of the RAME at a function of solution $\mathrm{pH}$ in presence of $1.0 \times 10^{-4} \mathrm{~mol} \mathrm{dm}^{-3}$ hydrazine, $w=200 \mathrm{rpm}, \mathrm{E}_{a p p}=300 \mathrm{mV}$. [in the box: Cyclic voltammograms obtained for RAME in presence and absence of hydrazine

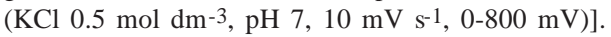

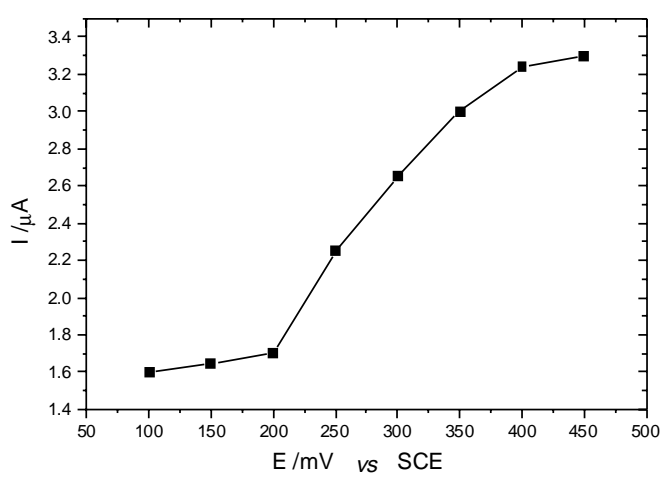

Figure 8. Dependence on the oxidation peak currents of the RAME at a function of applied potential in $\mathrm{pH} 7$, in presence of $1.0 \times 10^{-4}$ mol dm-3 hydrazine, $w=200 \mathrm{rpm}$.

The detection limit was of $5.0 \times 10^{-6} \mathrm{~mol} \mathrm{dm}^{-3}$ determined as 3 times the noise level and the sensitivity was of $30 \mathrm{~mA} \mathrm{dm}{ }^{3} \mathrm{~mol}^{-1}$. Furthermore this system showed very good repeatability after 30 measurements with a relative standard deviation of $0.48 \%$.

The reaction order (1.01) for hydrazine oxidation obtained from the curve $\ln$ i $v s$. ln $\mathrm{c}$ (not shown) fit by the equation $\ln \mathrm{i}=-3.5( \pm 0.1)+\underline{1.01}( \pm 0.01) \ln \mathrm{c}$ is somewhat higher than values reported for platinum electrodes, where the reaction order was about $0.5^{20}$. In addition, the response time for chronoamperometric measurements was very short, being necessary only $1 \mathrm{~s}$ to reach the maximun response. It shows that the catalytic activity of RAME for hydrazine oxidation is higher than those observed for other systems ${ }^{20-23}$.

\section{Conclusions}

The potentialities of these complexes for sensors construction were evaluated showing to be very promising for sensing molecules of biological interest, mainly if they could interact through their axial positions. In the hydrazine case, the detection limit is not very low, but this system presented a wide linear response range and it can be useful for sensors. The very short response time $(1 \mathrm{~s})$ could be very attractive to apply in flow injection analysis. Other good characteristic of RAME was the relative low applied potential $(\sim 300 \mathrm{mV})$ for hydrazine detection. Besides, the electrochemistry of these complexes could add more information to the rhodium's chemistry, specially for dimers, helping a better understanding of many mechanisms including the catalytic and citostatic activity.

\section{Acknowledgments}

The authors thank Prof. Renato Najjar, Prof. Aparecido Ribeiro de Souza and Breno Pannia Esposito for the important help with the discussions about the synthesis and FAPESP for the financial support.

\section{References}

1. Kubota, L. T.; Gouvea, F.; Milagres, B. G.; Andrade, A. N.; Oliveira Neto, G. de Electrochim. Acta 1996, $41,1465$.

2. Gorton, L. Electroanalysis 1995, 7, 23.

3. Gilmartin, M.A. T.; Hart, J. P. Analyst 1995, 120, 1029.

4. Csöregi, E.; Gorton, L.; Marko-Varga, G.; Tudos, A. J.; Kok, W. T. Anal. Chem. 1994, 66, 3604.

5. Bindra, D. S.; Zhang,Y.; Wilson, G. S.; Sternberg, R.; Thevenot, D. R.; Moatti, D.; Reach, G. Anal. Chem. 1991, 63, 1692.

6. Gorton, L.; Jonsson, P.; Csöregi, E.; Johansson, K.; Dominguez, E.; Marko-Varga, E. Analyst 1992, 117, 1235.

7. Milagres, B. G.; Oliveira Neto, G. de; Kubota, L. T. Electroanalysis 1996, 8, 489.

8. Kalcher, K.; Kauffmann, J. M.;Wang, J.; Svancara, I.; Vytras, K.; Neuhhold, C.; Zhongping, Y. Electroanalysis 1995, 7, 1.

9. Brett, A. M. O.; Serrano, S. H. P.; La-Scalea, M. A. Electroanalysis 1996, 8, 1237.

10. Gil, E. S.; Najjar, R.; Kubota, L. T. Quim. Nova 1998, $21,755$.

11. Bear, J. L. Cancer Chemother. Rep. 1975, 59, 611.

12. Boyar, E. B.; Robinson, S. D. Coord. Chem. Rev. 1983, $50,109$. 
13. Doyle, M. P.; Bagheri, V.; Wandless, T. J.; Harn, N. K.; Brinker, D. A.; Eagle, C. T.; Loh, K. L. J. Am. Chem. Soc. 1990, 112, 1906.

14. Perez, E. F.; Oliveira Neto, G. de; Tanaka, A. A.; Kubota, L. T. Electroanalysis 1997, 10, 111.

15. Casella, I. G.; Guascito, M. R.; Salvi,A. M.; Desimini, E. Anal. Chim. Acta 1997, 354, 333.

16. Zagal, J. H.; Lira.S.; Ureta-Zanãrtu, S. J. Electroanal. Chem. 1986, 210, 95.

17. Duncan, J.; Malinski, T.; Zhu, T. P.; Hu, Z. S.; Kadish, K. M. J. Am. Chem. Soc. 1982, 104, 5507.
18. Chavan, M. Y.; Zhu, T. P.; Lin, X. Q.; Ahsan, M. Q.; Bear, J. L.; Kadish, K. M. Inorg. Chem. 1984, 23, 4538.

19. Zhu, T. P.; Ahsan, M. Q.; Malinski, T.; Kadish, K. M.; Bear, J. L. Inorg. Chem. 1984, 23, 2.

20. Garcia, M. D.; Marcos, M. L.; Velasco, J. G. Electroanalysis 1996, 8, 267.

21. Zagal, J. H. Coord. Chem. Rev. 1992, 119, 89.

22. Yu, A.; Chen, H. Anal. Lett. 1997, 30, 599.

23. Guerra, S. V.; Xavier, C. R.; Nakagaki, S.; Kubota, L. T. Electroanalysis 1998, 10, 462.

Received: September 16, 1999

FAPESP helped in meeting the publication costs of this article. 